\title{
Afrika Focus - Guidelines for authors
}

(I) Languages. Afrika Focus only accepts articles in Dutch, French and English. The language should be correct with regard to style, vocabulary and spelling.

(2) Cover page. Each article opens with a cover page with the following information: (a) the name, affiliation(s), address and electronic address of the author(s), (b) an abstract of no more than 200 words, summarizing the main objectives and the conclusions of the article, in the language of the article (when the article is not written in English, the author should also provide an English translation of the abstract), (c) a maximum of five keywords in the language of the article, as well as in English, and (d) possibly a word of thanks (in print these words of thanks will be put at the end of the article, after the text and before the references).

(3) Layout. The text should be laid out as follows: (a) double-spaced with font 12 throughout, including the citations, bibliographical references, titles and captions, (b) margins of $2.5 \mathrm{~cm}$. on top, at the bottom, left and right. The main text should be no longer than 30 pages (double-spaced), except for special arrangements with the chief or guest editors. Avoid splitting words at the end of the line. Each new paragraph should be clearly indicated, as should the titles. Titles should be ordered without numbering, with a maximum of two levels.

(4) Quotations. Quotations, expressions in Latin or in any other foreign language, etc... should be marked by italics.

(5) Footnotes. Footnotes should be kept to a minimum: authors should check to make sure that a footnote does not give redundant information. Footnotes should be numbered consecutively and typed at the end of the text.

(6) Tables. Tables should be numbered separately and carry clear captions. Arrangements will be made with the publisher regarding the size and layout of the tables. These arrangements are binding.

(7) Figures. Figures should be submitted electronically and separate from the text. The format can be either TIFF, with a minimum resolution of $300 \mathrm{dpi}$, a high-resolution JPEG, or a PDF with printing quality. Afrika Focus does not accept figures in GIF-, MS Word- or MS Excel-format. All figures (drawings, graphs, pictures or maps) should be numbered consecutively. The reader should be able to clearly interpret graphs printed in black-and-white. Each figure should have a brief and clear legend. All aspects of the figures, including letters, should be large enough to still be legible when reduced in size.

(8) References. Afrika Focus largely follows the APA reference system (http://www.apastyle.org/) with regard to references cited in the text and the reference section at the end of the article.

(9) References in the text. References in the text should read:

a) name of the author in lower-case, followed by a comma and the year of publication, possibly followed by a colon and the page reference (Janssens, 1975: 5-15)

b) if there are two authors (Janssens \& Peterson, 1975: 5-15)

c) if there are more than two authors (Janssens et al., 1975: 5-15).

(10) Reference list. All text references should be listed at the end of the article, in alphabetical order of the authors and, for the same author (or group of authors), in chronological order.

The bibliographical references should read as follows:

- In case of an article from a journal:

Last name of the author, First name (date). Title of the article. Title of the journal, volume (number): pages.

- In case of an article from a book:

Last name of the author, First name (date). Title of the article. In A. Editor (ed.), Title of the book, pp. x-x. Place of publication: Publisher.

- In case of a book:

Last name of the author, First name (date). Title of the book. Place of publication: Publisher, pages.

- In case of proceedings (conference, symposium, etc...):

Last name of the author, First name (date). Title of the article. In: Title of the proceedings, pp. $x$-x. Place, date.

(iI) Offprints. Each author receives two copies of the journal and can give two names and addresses of persons who will receive a copy of the journal. Additionally, the author will also receive a final PDF of his/her article.

(12) Suggesting reviewers. Authors can submit a list of up to 6 persons (connected to research institutions) eligible to review their article. The editors are not obliged to comply with these suggestions, but they will respect requests regarding the exclusion of certain reviewers.

(13) Submission. The manuscript should be submitted digitally to the editorial secretariat, as a Word document attached to an email. The author will receive confirmation of the receipt of the manuscript. 


\section{Afrika Focus - Instructions pour auteurs}

(I) Langues. Afrika Focus accepte des articles en néerlandais, français et anglais. La langue doit être utilisée correctement en ce qui concerne le style, le vocabulaire et l'orthographe.

(2) Page de titre. Chaque article sera précédé d'une page de titre qui contiendra (a) le(s) nom(s), l'affiliation/les affiliations, l'adresse, et le courriel d'auteurs,(b) d'un résumé, de maximum 200 mots rédigé dans la langue de l'article, qui résumera les objectifs et les résultats, (si l'article n'est pas en anglais, l'auteur fournira également une traduction en anglais), (c) maximum cinq mots clés dans les deux langues respectives, et $(\mathrm{d})$ en cas de remerciements (ceux-ci seront publiés à la fin de l'article, après le texte mais précédant la liste des références).

(3) Présentation du manuscrit. Le texte intégral en Times New Roman doit être fourni à double interligne. Une police de 12 points sera utilisée pour le texte intégral, y compris les citations, les références bibliographiques, les titres et les entêtes. Les marges sont de $\mathbf{2 , 5} \mathrm{cm}$ en haut, et bas de page, à gauche et à droite. Le texte principal ne doit pas excéder 30 pages (double interligne), à moins qu'il en soit convenu autrement avec les Rédacteurs en Chef. Eviter de scinder les mots en fin de phrase. Chaque nouveau paragraphe ou titre est indiqué clairement. Les titres ne sont pas numérotés et en outre limités à deux niveaux.

(4) Citations. L'italique est utilisé pour mettre en évidence les citations, les expressions en latin ou autre langue.

(5) Notes infrapaginales. Les notes infrapaginales sont limitées au stricte minimum : les auteurs doivent se poser la question si ce qui a été intégrer dans la note est vraiment important. La numérotation de celles-ci est continue et elles sont présentées à la fin de l'article.

(6) Tableaux. Les tableaux sont numérotés séparément et pourvus d'une légende. Les dimensions et la mise en page sont à convenir avec l'éditeur. Cet accord est contraignant.

(7) Illustrations. Les illustrations sont fournies électroniquement et séparément, soit en format TIFF avec une résolution de $300 \mathrm{dpi}$, soit en format JPEG à haute résolution, soit en format PDF, qualité d'impression. Afrika Focus n'accepte pas les illustrations fournies en format GIF, Word ou Excel. Toutes les figures (y compris dessins, graphiques, photos ou cartes) doivent être numérotées en continu. Les graphiques imprimés en noir et blanc doivent être lisibles. Chaque illustration est pourvue d'une légende claire et brève. Tous les éléments des figures, lettres inclues, doivent être assez grands afin d'être lisibles après réduction.

(8) Système de référence. Afrika Focus suit en grandes lignes le système APA (http ://www.apastyle.org) pour l'intégration des références dans le texte et la mise en page de la liste des références à la fin de l'article.

(9) Références dans le texte. Dans le texte on réfere à la liste des références de la manière suivante :

a) Le nom de l'auteur en minuscule, suivi d'une virgule, l'année de publication, éventuellement suivie d'un double point et de la page (Janssens, $1975: 5$-15);

b) s'il y a deux auteurs : (Janssen \& Peterson, 1975:5-15)

c) plus de deux auteurs : (Janssen et al., 1975:5-15).

(Io) Liste des références. La liste des références vient à la fin de l'article et mentionne toutes les publications citées. Les références sont classées par ordre alphabétique et chronologique en fonction du nom du premier auteur (ou groupe d'auteurs).

Les références bibliographiques suivent les règles suivantes :

- Pour un article dans une revue, on indiquera :

Nom de l'auteur, Prénom (date). Titre de l'article. Titre de la revue, volume (numéro) : pages.

- Pour un article dans un livre, on indiquera :

Nom de l'auteur, Prénom (date). Titre de l'article. Dans A. Rédacteur (red.), Titre du livre, pp. $\mathrm{x}$-x. Lieu d'édition : Editeur.

- Pour un livre, on indiquera :

Nom de l'auteur, Prénom (date). Titre du livre. Lieu d'édition : Editeur, pages.

- Pour les actes de colloques (congrès, symposium, etc...), on indiquera :

Nom de l'auteur, Prénom (date). Titre de l'article. Dans : Titre des actes, pp. x-x. Lieu, date.

(II) Tirés à part. Deux exemplaires de la revue seront remis à l'auteur. L'auteur peut également communiquer deux adresses auxquelles un exemplaire sera envoyé. En outre, l'auteur reçoit son article en PDF.

(12) Proposition de lecteurs. Les auteurs peuvent proposer 6 personnes au maximum (attachées à un institut de recherche) qu'ils estiment valables en tant que lecteur. La rédaction n'est pas obligée d'accepter ces suggestions mais respectera en outre la demande d'exclusion de certains lecteurs.

(13) Indication de mise en page. Le manuscrit doit être adressé en format Word, par courriel au secrétariat de rédaction. Les auteurs reçoivent un accusé de réception. 


\section{Description peer review process Afrika Focus}

The review process of the journal Afrika Focus takes place according to the following procedure:

(I) Before submission, authors are requested to consult the journal's guidelines for authors: http://www.gap.ugent.be/For authors. Authors are encouraged to bear in mind that Afrika Focus is a multidisciplinary journal with an academically and geographically diverse audience.

(2) After finalizing their paper according to these guidelines, authors submit it to the journal's secretariat: afrikafocus@ UGent.be.

(3) The editorial secretariat sends an immediate acknowledgement of receipt of the submission.

(4) The paper will be pre-reviewed by one of the editors-in-chief and within a few days this editor-in-chief decides whether a submitted paper satisfies the journal's criteria for review. If the paper does not comply with the criteria of the journal, the editor sends a mail with arguments for rejection and, if possible, a helpful recommendation to the author(s) for submission elsewhere.

(5) When the article is accepted for review, the editor-in-chief selects three peer reviewers with an international publication record, upon which the paper and a standard evaluation form are forwarded to these reviewers by the editorial secretariat. The e-mail letter sent by the editorial secretariat will set a deadline of one month. The author(s) will be informed that the review process takes no longer than six weeks.

(6) Depending on the reviewers and the paper, reviews may take between a few days and two months. The average review time of a paper is one month.

(7) After one month, reviewers who have not yet sent a review will be reminded to send their review as soon as possible.

(8) In case a reviewer has requested more time, the author(s) will be kept informed of the delay.

(9) Reviewers decide whether a paper admitted to the review process is to be rejected, resubmitted or accepted by filling in the evaluation form. Accepted papers are commonly recommended to undergo a list of well-determined revisions. These qualify as 'minor changes'. Resubmission applies to papers attracting the reviewers yet requiring major amendments.

(10) The editorial secretariat informs the authors about the decision of the reviewer(s), sends them a copy of the review, and - if the paper is accepted - instructions for the preparation of the next draft version.

(II) Papers that have to be resubmitted are being evaluated as if they were new submissions; this usually happens by the same reviewer(s). This/these reviewer/s check/s whether the required alterations have been implemented and whether the end result can be accepted.

(12) Final versions of accepted papers should be sent to the editorial secretariat, together with a filled out, printed, signed and scanned Publishing Agreement. The editorial secretariat immediately acknowledges receipt of the final version.

(13) The review process ends with a concluding reading of the paper by one of the editors-in-chief for a final check-up; the author is told whether the final version is accepted for publication and when the paper will be published.

(14) Papers that have been accepted are usually published in the journal issue appearing between 4 and 6 months after acceptance. This means that there is a waiting list of several months before papers/issues are being sent to the publisher.

(15) Each author receives two copies of the journal, as well as a PDF of the final version of the article. The paper will also be available through the Directory of Open Access Journals (http://www.gap.ugent.be/Online_en).

(16) Depending on the speed of the review and of the revision by the authors, as well as on the number of papers on the waiting list, total time between submission and publication of the papers may range between 6 and 12 months. 